Boise State University

ScholarWorks

Division of Research and Economic Development Publications and Presentations

2018

\title{
Applicability of Current HRA Quantification Techniques to Human Failures Related to Digital Control Systems
}

Harold S. Blackman

Boise State University

This is a post-peer-review, pre-copyedit version of a conference proceeding published in Advances in Human Error, Reliability, Resilience, and Performance: Proceedings of the AHFE 2018 International Conference on Human Error, Reliability, Resilience, and Performance, July 21-25, 2018, Loews Sapphire Falls Resort at Universal Studios, Orlando, Florida, USA. The final authenticated version is available online at doi: 10.1007/978-3-319-94391-6_11 


\title{
Applicability of Current HRA Quantification Techniques to Human Failures Related to Digital Control Systems
}

\author{
Harold S. Blackman \\ Boise State University, Boise Idaho, USA
}

\begin{abstract}
This paper examines current error quantification techniques to determine their applicability to failures related to digital control systems. Methods are examined for relevant categories of analysis using design principles from digital control and display guidance. In addition, inherent differences at the system and task are examined for instances that might contribute to performance shaping factors not addressed or defined in current methods. The premise being that if digital systems are designed to meet design standards such as readability, information density, illumination, organization-location, etc. then, perhaps current methods may be applicable. Identification of and presentation of fundamental differences are presented along with recommendations for potential accommodations to current quantification techniques and future directions.
\end{abstract}

Keywords: Human Reliability • Human Error • Digital Systems

\section{Introduction}

With the advent of and introduction of digital systems into control rooms concern has generally been expressed about our ability to quantitatively assess the reliability of such systems including both the underlying software as well as the human's reliability in interacting with such systems. This paper is concerned with the assessment of human failures and our ability to apply current generation human reliability techniques to digital applications. The fundamental question is whether or not current methods have the ability to assess potential failures associated with these digital control systems. This is likely of more interest to those industries that are regulated in a risk informed manner such as the US nuclear industry as it is important that these entities are capable of providing human reliability information to inform their risk models as digital systems are introduced.

This paper is more of a thought experiment than a formal investigation. Other papers have explored this topic from a variety of perspectives including data needs, an approach to modify current techniques, and or actual data collection [1] [2]. I am posing the following question: is it possible, because of the way current methods are built, that the results from the application of these methods to digital systems are sufficient? 
This is an author-produced, peer-reviewed version of this article. The final, definitive version of this document can be found online at Advances in Human Error, Reliability, Resilience, and Performance: Proceedings of the AHFE 2018 International Conference on Human Error, Reliability, Resilience, and Performance, July 21-25, 2018, Loews Sapphire Falls Resort at Universal Studios, Orlando, Florida, USA, published by Springer. Copyright restrictions may apply. doi: 10.1007/978-3-319-94391-6_11

\section{The Case}

For decades, human factors specialists have conducted experimental work to understand how to improve interfaces resulting in countless guidelines that are employed by designers. These guidelines take the form of military standards, professional standards as well as numerous articles and textbooks. The standards and guidelines are updated at varying intervals dependent on the authoring organization. For example, the work done by the United States Nuclear Regulatory Commission in NUREG 0700 which was revised in 2002 [3] broadly addresses human-system interfaces. The guidelines that compose these standards are in most cases, in one form or another, instantiations of performance shaping factors (PSFs). For example, for a general category such as display quality (think human machine interface for the PSF) you will find a variety of guidelines for design such as character height-to-width ratios, character font types, illumination, information density, grouping and use of color just to name a few. These guidelines cover the entire range of possible environments a human may find themselves in, as well as internal factors, including environmental conditions, personal factors, noise, motion, illumination, human capabilities (output and control), motor skills, labeling, fonts, readability, meaningfulness, as well as auditory, tactual, and olfactory components. In addition, these guidelines cover both analog and digital systems. It is also the case that these guidelines are based upon fundamental research as well as years of experience. Arguably, it is the case that human reliability methods also use factors of a similar nature as well as some of the same underlying research for support. So do HRA methods at least cover the guidance used to design digital systems optimally?

\section{Method and Guidelines Comparisons}

So to answer this question I chose a few design categories relevant to human machine interfaces, then considered each of three HRA methods SPAR-H [4], CREAM [5], and HEART [6] to see if they there was sufficient information to consider those same categories. The concept simply being that if there is a fit then at least that category could be accounted for. The categories I selected were alarms, information displays, and computer based procedures and are in found in Table 1 below.

Table 1. Design Guideline Categories.

\begin{tabular}{|l|l|l|}
\hline Alarms & Information Displays & $\begin{array}{l}\text { Computer Based } \\
\text { Procedures }\end{array}$ \\
\hline Timeliness & Functional relationships & Flexible navigation \\
\hline Effective coding & Reducing ambiguity & $\begin{array}{l}\text { User control and user } \\
\text { pace }\end{array}$ \\
\hline
\end{tabular}


This is an author-produced, peer-reviewed version of this article. The final, definitive version of this document can be found online at Advances in Human Error, Reliability, Resilience, and Performance: Proceedings of the AHFE 2018 International Conference on Human Error, Reliability, Resilience, and Performance, July 21-25, 2018, Loews Sapphire Falls Resort at Universal Studios, Orlando, Florida, USA, published by Springer. Copyright restrictions may apply. doi: 10.1007/978-3-319-94391-6_11

\begin{tabular}{|l|l|l|}
\hline Nuisance avoidance & Data abstraction & Simple wording \\
\hline Alarm signal validation & Understandability & Warnings and cautions \\
\hline & & $\begin{array}{l}\text { Hierarchical logical } \\
\text { organization }\end{array}$ \\
\hline
\end{tabular}

I then briefly reviewed the subcategories for each of these to see what kind of guidelines were suggested. The lists are of course only partial, but are meant to reflect the level of guidance given, and the kinds of considerations being made.

So turning to the three methods I have identified the following factors that align with categories.

Table 2. Guidelines and HRA Factor Alignment.

\begin{tabular}{|c|c|c|c|}
\hline Category & SPAR-H & CREAM & HEART \\
\hline Alarms & $\begin{array}{l}\text { Ergonomics- } \\
\text { missing or } \\
\text { misleading, poor, } \\
\text { nominal, good }\end{array}$ & $\begin{array}{l}\text { Adequacy of MMI } \\
\text { and operational } \\
\text { support- supportive, } \\
\text { adequate, tolerable, } \\
\text { inappropriate }\end{array}$ & $\begin{array}{l}\text { Low signal-noise } \\
\text { ratio, a means of } \\
\text { suppressing or over- } \\
\text { riding information } \\
\text { of features which is } \\
\text { too easily } \\
\text { accessible, poor, } \\
\text { ambiguous or ill- } \\
\text { matched system } \\
\text { feedback, no } \\
\text { diversity of } \\
\text { information input } \\
\text { for veracity checks }\end{array}$ \\
\hline $\begin{array}{l}\text { Information } \\
\text { displays }\end{array}$ & $\begin{array}{l}\text { Ergonomics- } \\
\text { missing or } \\
\text { misleading, poor, } \\
\text { nominal, good }\end{array}$ & $\begin{array}{l}\text { Adequacy of MMI } \\
\text { and operational } \\
\text { support- supportive, } \\
\text { adequate, tolerable, } \\
\text { inappropriate }\end{array}$ & $\begin{array}{l}\text { No means of } \\
\text { conveying spatial } \\
\text { and functional } \\
\text { information to } \\
\text { operators in a form } \\
\text { they can readily } \\
\text { assimilate, no } \\
\text { diversity of } \\
\text { information input } \\
\text { for veracity checks, } \\
\text { unreliable }\end{array}$ \\
\hline
\end{tabular}


This is an author-produced, peer-reviewed version of this article. The final, definitive version of this document can be found online at Advances in Human Error, Reliability, Resilience, and Performance: Proceedings of the AHFE 2018 International Conference on Human Error, Reliability, Resilience, and Performance, July 21-25, 2018, Loews Sapphire Falls Resort at Universal Studios, Orlando, Florida, USA, published by Springer. Copyright restrictions may apply. doi: 10.1007/978-3-319-94391-6_11

\begin{tabular}{|l|l|l|l|}
\hline & & & $\begin{array}{l}\text { instrumentation } \\
\text { (enough that it is } \\
\text { noticed), no } \\
\text { obvious way of } \\
\text { keeping track of an } \\
\text { activity, } \\
\text { inconsistency of } \\
\text { meaning between } \\
\text { displays and } \\
\text { procedures }\end{array}$ \\
\hline $\begin{array}{l}\text { Computer-based } \\
\text { procedures }\end{array}$ & $\begin{array}{l}\text { Procedures- not } \\
\text { available, } \\
\text { incomplete, } \\
\text { available but poor } \\
\text { or nominal }\end{array}$ & $\begin{array}{l}\text { Availability of } \\
\text { procedures/plans- } \\
\text { appropriate, } \\
\text { acceptable, or } \\
\text { inappropriate }\end{array}$ & $\begin{array}{l}\text { Ambiguity in } \\
\text { performance } \\
\text { standards, an } \\
\text { impoverished } \\
\text { quality of }\end{array}$ \\
& & $\begin{array}{l}\text { information } \\
\text { conveyed by } \\
\text { procedures and } \\
\text { person/person } \\
\text { interaction, little or } \\
\text { no intrinsic } \\
\text { meaning in a task, } \\
\text { inconsistency of } \\
\text { meaning of displays } \\
\text { and procedures }\end{array}$ \\
\hline
\end{tabular}

At least for this partial sample, it was very straightforward to find appropriate categories covering the individual guidelines selected. Of course this is not an exhaustive comparison, but based on this limited effort it would seem that coverage does indeed exist. Taking that at face value then it would appear that HRA methods do reflect the optimal design of digital systems.

So, in addition to the fact that the methods do cover the design guidelines, a closer examination of human reliability methods also quickly points out that the level of specificity of factors is at a level generally above specifying a specific modality of display or control. You must go back to THERP [7] to find data at the level of specific types of controls and or displays for example a failure rate for a digital readout versus a chart recorder (Table 20-10, NUREG-1278) [7]. SPAR-H, CREAM, and HEART all operate at a level above this attempting to define conditions that generally can produce error using combinations of task types, contextual factors, and both physical and psychological factors such as error producing conditions, common performance conditions, or more generically performance shaping factors. So for a particular task type with a knowledge of 
This is an author-produced, peer-reviewed version of this article. The final, definitive version of this document can be found online at Advances in Human Error, Reliability, Resilience, and Performance: Proceedings of the AHFE 2018 International Conference on Human Error, Reliability, Resilience, and Performance, July 21-25, 2018, Loews Sapphire Falls Resort at Universal Studios, Orlando, Florida, USA, published by Springer. Copyright restrictions may apply. doi: 10.1007/978-3-319-94391-6_11

the conditions associated with that task you can define levels of various conditions or factors known to impact performance. Different methods define and combine these task types, definitions and factors in different ways, but really all from the same theoretical perspective, and all based on the same literature given the era on the method's creation.

To date many have concluded that since digital controls are not specifically mentioned by the HRA methods that they are not applicable. Perhaps it is more accurate to say that since the methods take a more agnostic approach to the type of the display/control (digital or analog) and only pay attention to those characteristics that impact performance that they are applicable. With a judicious application of the methods it is possible you can account for such differences within the constraints of the given method.

\section{Data}

This takes us to the question of data. It is well known that human reliability assessment techniques have their roots in data that has collected from a variety of sources including plant and industry specific data, simulator data, experimental studies, and expert opinion. Much of the original data came from an era that did not have digital systems, but more recently researchers have been updating data and or collecting new data that likely include digital systems. The most recent and comprehensive effort looking at data for HRA has been completed by Jeremy Williams and Julie Bell specifically for the Human Error Assessment and Reduction Technique or HEART. They have completed a review of over 35,000 papers identifying 175 usable data sources [8]. This review included studies that used a variety of tasks and systems with the conclusion that the quantitative data underlying the tasks types and conditions for the HEART method were supported. This is encouraging information again suggesting that the quantitative values in HEART and perhaps by extension other current HRA methods may indeed be appropriate.

\section{Conclusions}

This cursory study has demonstrated that HRA methods do have the capacity to cover the design factors that optimize digital system design, which suggests the methods may be applicable for analysis. In addition, work is continuing by method's developers (HEART specifically) to update data upon which their methods are based which is proving to be supportive of the general failure distributions currently in found in the methods. It may be that as developer's continue to update their data that the available HRA methods may be appropriate for application to digital systems. Certainly should work should continue and be conducted by other developers to assure the risk community of their validity. 
This is an author-produced, peer-reviewed version of this article. The final, definitive version of this document can be found online at Advances in Human Error, Reliability, Resilience, and Performance: Proceedings of the AHFE 2018 International Conference on Human Error, Reliability, Resilience, and Performance, July 21-25,

2018, Loews Sapphire Falls Resort at Universal Studios, Orlando, Florida, USA, published by Springer. Copyright restrictions may apply. doi: 10.1007/978-3-319-94391-6_11

\section{References}

1. Boring, R. L.: Human Reliability Analysis for Digital Human-Machine Interfaces: A Wish List for Future Research (2014).

2. Boring, R. L. and Gertman D. J.: Consideration for the treatment of computerized procedures in human reliability analysis, 8th International topical Meeting in Nuclear Power Plant Instrumentation Control and Human-Machine Interface Technologies (NPIC \& HMIT) 1476-1487 (2012).

3. O'Hara, M., Brown, W., Lewis, P., and Persensky, J: Human-System Interface Design Review Guidelines, NUREG-0700, Washington, DC: US Nuclear Regulatory Commission (2002).

4. Gertman, D., Blackman, H., Marble, J., Byers, J., \& Smith, C.: The Spar-H Human Reliability Analysis Method, NUREG/CR-6883, Washington, DC: US Nuclear Regulatory Commission (2005).

5. Williams, J.C.: A data-based method for assessing and reducing human error to improve operational performance, IEEE fourth conference on human factors and power plants (pp. 436-450), Monterey, California (1988).

6. Hollnagel, Eric: Cognitive Reliability and Error Analysis Method CREAM, Elsevier, Oxford, England (1988).

7. Swain A. D. and Guttmann H: Handbook for human reliability analysis with emphasis on nuclear power plant applications, NUREG/CR-1278, U.S. Nuclear Regulatory Commission (1983).

8. Williams, Jeremy and Bell, Julie: Consolidation of the Generic Task Type database and concepts used in the Human Error Assessment and Reduction Technique (HEART), Safety and Reliability, 36:4, 245-278, (2016). 